\title{
Genetic structuring among populations of the greenshell mussel Perna canaliculus revealed by analysis of randomly amplified polymorphic DNA
}

\author{
Bastiaan Star ${ }^{1,2}$, Smita Apte ${ }^{1}$, Jonathan P. A. Gardner ${ }^{1, *}$ \\ ${ }^{1}$ School of Biological Sciences, Victoria University of Wellington, PO Box 600, Wellington, New Zealand \\ ${ }^{2}$ Present address: Mariene Biologie, Rijksuniversiteit Groningen, Kerklaan 30, 9751 NN Haren, The Netherlands
}

\begin{abstract}
Allozyme analysis of 35 populations of the endemic New Zealand greenshell mussel Perna canaliculus (Gmelin 1791) indicated an absence of genetic structuring, whereas mitochondrial DNA (mtDNA) single-strand conformation polymorphism (SSCP) analysis of 22 of the same populations indicated a pronounced genetic discontinuity between northern and southern mussels at $\sim 42^{\circ} \mathrm{S}$ latitude. The present study examines the genetic structuring of a subset of $19 \mathrm{New}$ Zealand mussel populations using the randomly amplified polymorphic DNA (RAPD) technique. A genetic discontinuity was observed between northern and southern populations, which resulted from significant allele frequency differences, but no absolute differences between populations of these regions. Southern populations were genetically more diverse than northern populations, with the west coast of the South Island being the most distinct from northern populations. The RAPD data are consistent with the mtDNA data, indicating that both studies have resolved the population structure of $P$. canaliculus at a higher level than previous allozyme studies. The location of the genetic discontinuity coincides with major hydrographic features at $\sim 42^{\circ} \mathrm{S}$ latitude. We hypothesise that restricted gene flow (larval transport), a consequence of present day coastal surface circulation patterns, influences the population genetic structuring of this species, an effect which is relatively recent in geological time (within the last $12000 \mathrm{yr}$ ).
\end{abstract}

KEY WORDS: Population genetics $\cdot$ Gene flow $\cdot$ Hydrography $\cdot$ RAPD $\cdot$ New Zealand $\cdot$ Perna canaliculus $\cdot$ Mussel

Resale or republication not permitted without written consent of the publisher

\section{INTRODUCTION}

The endemic New Zealand greenshell mussel Perna canaliculus (Gmelin 1791) is a benthic marine organism with a sessile adult stage and a pelagic larval stage (Hayden 1994). It is commonly found on lower intertidal and sublittoral hard shores, and is continuously distributed throughout New Zealand with a latitudinal range of $>2000 \mathrm{~km}$, from $\sim 35$ to $\sim 47^{\circ} \mathrm{S}$ (Smith 1988). This mussel is both important ecologically because of its widespread distribution and biomass, and economically because it is the only cultivated species in New Zealand (Jones 2000). Like many marine invertebrate species, $P$. canaliculus is a broadcast spawner that potentially produces millions of offspring per individ-

${ }^{*}$ Corresponding author. Email: jonathan.gardner@vuw.ac.nz ual, and has a larval stage that is dispersed by on surface currents (Hayden 1994). Because the larvae can remain viable in the water column for $>4 \mathrm{wk}$ (Buchanan 1994) they can be transported over 100s of $\mathrm{km}$. These life-history attributes suggest that gene flow can be very high, with a potentially homogenizing effect that prevents genetic differentiation among populations of this species (Apte \& Gardner 2001). However, despite the fact that the majority of nearshore marine species possess long-lived planktonic larval stages with high dispersal potential, there is increasing evidence from genetic markers that many populations do not receive or contribute to the high levels of gene flow that such life history characteristics would imply (Hellberg et al. 2002, Swearer et al. 2002). The ecolog- 
ical literature also now suggests that patterns of larval recruitment (i.e. gene flow) are not as simple (i.e. widespread) as had been assumed, but are profoundly influenced over both short-term (days to weeks) and long-term (years to decades) spatial scales by small geographic-scale processes such as upwelling, downwelling, and gyres, and also by larger scale processes such as the El Niño-Southern Oscillation (ENSO) events (refer to Botsford 2001, and references therein). To study the genetic connectivity among, and genetic structuring within, populations of a coastal invertebrate, New Zealand's greenshell mussel is an appropriate model organism, because we are able to examine the entire geographic range of this endemic species, which spans 12 degrees of latitude from the subtropical north to the cool temperate south.

Genetic structuring of populations of Perna canaliculus has been examined several times. The first study, using allozymes, reported significant genetic heterogeneity between 2 northern and 4 southern populations at 4 of 10 polymorphic loci (Smith 1988). Reduced gene flow as a consequence of local currents, and adaptation to different thermal conditions was thought to partially isolate the populations at $\sim 38^{\circ} \mathrm{S}$ latitude (Smith 1988). A second allozyme study observed significant genetic subdivision among 10 populations at 7 polymorphic loci, but no evidence was found that supported the previous north-south subdivision because an isolation-bydistance model of gene flow was the best explanation for the observed genetic heterogeneity (Gardner et al. 1996). A third allozyme study of 7 polymorphic loci among 35 populations revealed no significant genetic heterogeneity among the sampled populations and a model of panmixia best explained the observed absence of population genetic subdivision (Apte \& Gardner 2001). While most allozyme loci are typically considered to be selectively neutral, it is possible that differences in the loci assayed (in particular, the aminopeptidase loci) among the 3 studies might have contributed to the contrasting patterns of population genetic structuring (Apte \& Gardner 2001). The most recent study, using mitochondrial DNA (mtDNA) single-strand conformation polymorphism (SSCP) of 20 of the populations studied in Apte \& Gardner (2001), with 2 additional populations, reported significant population genetic structuring (Apte \& Gardner 2002). Because of the presence of a unique SSCPhaplotype at $\sim 20 \%$ frequency among southern mussels and frequency shifts in other haplotypes, the populations could be separated into a northern and a southern group. The transition occurs abruptly, just below the northern end of the South Island at $\sim 42^{\circ} \mathrm{S}$ latitude, and south of Cook Strait (Apte \& Gardner 2002). Therefore, all 4 studies conducted to date have reported significant differences in the population genetic structuring of this mussel species.

To analyse the apparent discordance among previous studies we used the randomly amplified polymorphic DNA (RAPD) technique (Welsh \& McClelland 1990, Williams et al. 1990) which requires no prior knowledge of DNA sequence, generates large amounts of data for analysis, represents the entire genome (nuclear and mtDNA), and is faster and cheaper than many other molecular techniques. However, RAPD markers are dominant and can be hard to reproduce and score accurately, and require larger sample sizes than other techniques. Despite these potential limitations, RAPD markers have been employed successfully to examine genetic variation in a range of marine species (Adamkewicz \& Harasewych 1994, 1996, Patwary et al. 1994, Crossland et al. 1996, Smith et al. 1996, 1997, Caccone et al. 1997, Heipel et al. 1998, André et al. 1999, Hirschfeld et al. 1999, Sommerfeldt \& Bishop 1999, Ma et al. 2000, Goldson et al. 2001). Furthermore, RAPDs can be more informative than other marker types such as allozymes, because they can detect population structuring where allozymes reveal high levels of genetic similarity (Patwary et al. 1994, Heipel et al. 1998, Hirschfeld et al. 1999).

We constructed hypotheses to explain the discrepancy between our allozyme and mtDNA studies of Perna canaliculus, and to test these hypotheses we applied RAPD markers to the exact same individuals of 19 populations analysed previously (Apte \& Gardner 2001, 2002). We made the following assumptions about the different markers: (1) RAPD bands will most often be derived from nuclear DNA, rather than mtDNA, because the nuclear genome is much larger, (2) RAPDs will evolve rapidly because they are most likely to be found in non-coding regions, (3) the mtDNA molecule will evolve, on average, at a faster rate than comparable coding regions of the nuclear genome, (4) the effective population size of the mtDNA genome is $25 \%$ that of the nuclear genome, and (5) the allozyme markers are selectively neutral and will evolve less rapidly than the mtDNA markers. First, we hypothesised that some unknown historical event had resulted in differential patterns of genetic structuring within the mtDNA and the nuclear genomes. If this hypothesis is correct, then we predict that the RAPD markers will not exhibit evidence of genetic structuring, and will give similar results to those obtained from allozymes. Second, we hypothesised that both the mtDNA and nuclear genomes have been similarly affected, but that the genetic discontinuity is only apparent in the faster evolving mtDNA SSCP data, but not in the more conservative allozyme data (Apte \& Gardner 2002). If this hypothesis is correct, then we predict that the RAPD 
markers will exhibit a similar pattern of population genetic structuring to that exhibited by the mtDNA SSCP.

\section{MATERIALS AND METHODS}

Sample collection. The DNA was extracted from mussel tissue in the previous research (Apte \& Gardner 2002) (see Fig. 1 for locations). The mussels were dissected in the field, snap frozen in liquid nitrogen, and transferred to Victoria University of Wellington, New Zealand. Approximately $25 \mathrm{mg}$ of gonad tissue was taken from each individual. Total cellular DNA was extracted according to Rawson \& Hilbish (1995) and DNA extracts were stored at $-20^{\circ} \mathrm{C}$. Of the 35 populations used in the allozyme study (Apte \& Gardner 2001) and the 22 populations used in the mtDNA study (Apte \& Gardner 2002), 19 populations were used for this research.

PCR amplification. Aliquots of $30 \mu \mathrm{l}$ were taken from the $-20^{\circ} \mathrm{C}$ stocks. RNase (final concentration $54 \mathrm{U} \mathrm{ml}^{-1}$ ) was added to each DNA extract and samples were incubated at $37^{\circ} \mathrm{C}$ for $30 \mathrm{~min}$. The samples were diluted 10 times based upon results from previous research (Apte \& Gardner 2002). A modified version of the amplification protocol developed by Williams et al. (1990) was used. DNA amplification was performed in a volume of $25 \mu \mathrm{l}$, containing $1 \times$ PCR buffer (Gibco BRL ${ }^{\circledR}$, Life Technologies), $0.2 \mathrm{mM}$ of each deoxynucleotide (dATP, dCTP, dGTP, and dTTP), $2 \mathrm{mM} \mathrm{MgCl}_{2}, 0.2 \mu \mathrm{M}$ of each primer, $0.5 \mathrm{U}$ of Taq-polymerase (Gibco BRL ${ }^{\circledR}$, Life Technologies) and $10 \mathrm{ng}$ of template DNA. Mineral oil $(17 \mu \mathrm{l})$ was added on top of each reaction mixture to prevent evaporation, and all cups and solutions were kept on ice during the PCR preparations. All amplifications were performed in a Perkin-Elmer Cetus 480 DNA thermocycler, which was preheated to $95^{\circ} \mathrm{C}$ and programmed for 40 cycles: 4 initial cycles of $3 \mathrm{~min}$ each at 94, 36, and $72^{\circ} \mathrm{C}_{i}$ followed by 35 cycles of $30 \mathrm{~s}$ at $94^{\circ} \mathrm{C}, 1 \mathrm{~min}$ at $36^{\circ} \mathrm{C}$, and $2 \mathrm{~min}$ at $72^{\circ} \mathrm{C}_{i}$ and a final amplification of 1 cycle of $30 \mathrm{~s}$ at $94^{\circ} \mathrm{C}, 1 \mathrm{~min}$ at $36^{\circ} \mathrm{C}$ and $10 \mathrm{~min}$ at $72^{\circ} \mathrm{C}$ (Patwary et al. 1994).
During preliminary tests, 80 oligonucleotide primers from 4 different kits (Kits C, E, G, and I: Operon Technologies) were screened against 2 individuals, one from the Riverton population (South Island) and one from the Maunganui population (North Island). Fourteen primers were selected based on their ability to amplify reproducible and easily scorable DNA bands. These 14 primers were then screened for informative polymorphisms among a greater number of individuals from the same 2 test populations, and 3 primers were selected for subsequent use. These primers were $\left(5^{\prime}-\right.$ to $\left.-3^{\prime}\right)$ : OPC-15 (GACGGATCAG), OPG-12 (CAGCTCACGA), and OPI-04 (CCGCCTAGTC).

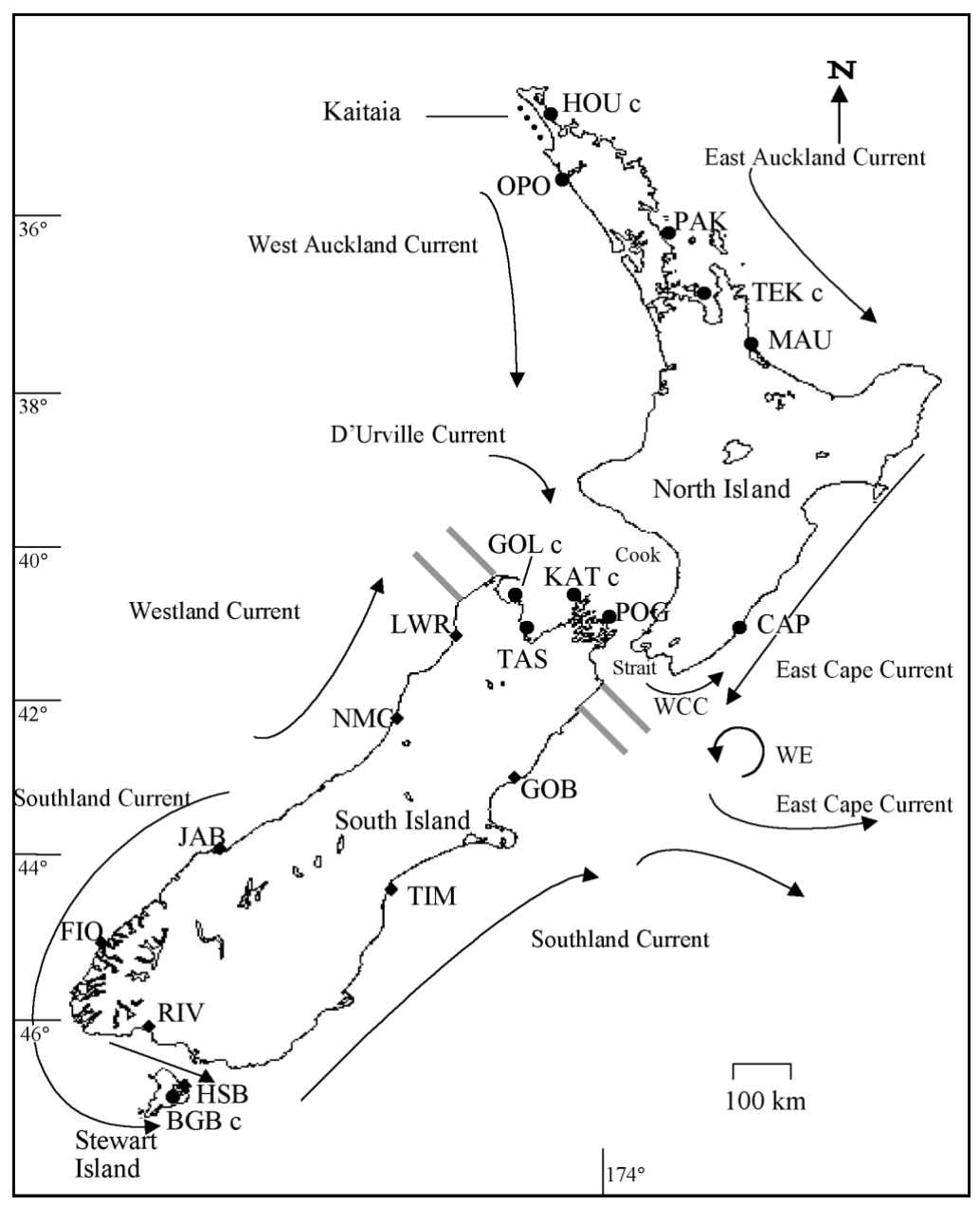

Fig. 1. Collection sites of Perna canaliculus and hydrographic patterns around New Zealand. Houhora (HOU); Opononi (OPO); Pakiri (PAK); Te Kouma (TEK); Maunganui (MAU); Golden Bay (GOL); Tasman Bay (TAS); Kaitaia (KAT); Port Gore (POG); Castlepoint (CAP); Little Wanganui River (LWR); Nine Mile Creek (NMC); Gore Bay (GOB); Jacksons Bay (JAB); Timaru (TIM); Fiordland (FIO); Riverton (RIV); Horseshoe Bay (HSB); Big Glory Bay (BGB). $\bullet$ : northern group; $\bullet$ : southern group; $\square$ : areas of coastal upwelling; -...: Kaitaia spat; c: cultured mussels; WE: Wairarapa Eddy; WCC: Wairarapa Coastal Current. Hydrographic data from Stanton (1976), Bowman et al. (1983), Barnes (1985), Heath (1985), Harris (1990), Vincent \& HowardWilliams (1991), Stanton \& Moore (1992), Chiswell (2000) 
Table 1. Perna canaliculus. Population number (No.), sampling site, sampling site code, type of population (W: wild; C: cultured), number of individuals analysed (N) in examinations of allozyme, mitochondrial DNA (mtDNA) markers, and randomly amplified polymorphic DNA (RAPD). N, S, St: North, South, and Stewart Island respectively

\begin{tabular}{|cllcl|}
\hline No. & Sampling site & Site code & Type & N \\
\hline 1 & Tasman Bay & TAS (S) & W & $20^{\text {a }}$ \\
2 & Big Glory Bay & BGB (St) & C & 22 \\
3 & Castlepoint & CAP (N) & W & 31 \\
4 & Te Kouma & TEK (N) & C & 30 \\
5 & Kaitaia & KAT (N) & C & 28 \\
6 & Maunganui & MAU (N) & W & 30 \\
7 & Opononi & OPO (N) & W & 30 \\
8 & Pakiri & PAK (N) & W & 30 \\
9 & Houhora & HOU (N) & C & 30 \\
10 & Port Gore & POG (S) & W & 20 \\
11 & Golden Bay & GOL (S) & C & 20 \\
12 & Fiordland & FIO (S) & W & 20 \\
13 & Gore Bay & GOB (S) & W & 30 \\
14 & Karamea & LWR (S) & W & 30 \\
15 & Punakaiki & NMC (S) & W & 30 \\
16 & Riverton & RIV (S) & W & 30 \\
17 & Jackson Bay & JAB (S) & W & 31 \\
18 & Timaru & TIM (S) & W & 27 \\
19 & Horseshoe Bay & HSB (St) & W & 23 \\
a Allozymes not examined & & & \\
\hline
\end{tabular}

Negative controls were run without template DNA alongside the DNA amplifications. One-third of each reaction product was separated by electrophoresis in $1.4 \%$ agarose TBE (Tris borate EDTA) gels $(10 \times 7.5 \mathrm{~cm})$ at $70 \mathrm{~V}$ for $3 \mathrm{~h}$. A $250 \mathrm{bp}$ DNA ladder (Gibco BRL ${ }^{\circledR}$, Life Technologies) was used as a molecular ruler. The products were stained in $1 \times$ TBE with ethidium bromide $\left(0.5 \mu \mathrm{ml}^{-1}\right)$ for $30 \mathrm{~min}$ and then destained for $15 \mathrm{~min}$. The DNA of the PCR products was visualized using UV illumination and gels were photographed using a Kodak DC 4800 digital camera with an orange filter. Corel Photopaint (Version 9.439) was used to invert the pictures and to increase contrast. The images were then printed on a Hewlett Packard 6MP laser printer for scoring of bands. PCR amplified DNA bands from each primer at specified positions in the gel were scored for their presence or absence in each individual. Preliminary tests showed bands were amplified consistently between 700 and $2000 \mathrm{bp}$, which is the estimated band size-range for the data collected. To ensure data accuracy, all photos were scored twice by the same individual (B.S.), and the second round of scoring was conducted without reference to data from the initial round. On re-scoring the entire data set, only 10 bands were scored differently compared to the first time of scoring. Because the entire data set contained $>10000$ bands for all individuals and all populations, it was concluded that band-scoring error was insignificant.
Data analysis. Data analysis was performed using the software programmes Tools for Population Genetic Analysis (TFPGA v1.3, by M. Miller; available at http:// bioweb.usu.edu/mpmbio), GenePop (v3.1d, Raymond \& Rousset 1995), and Statistical Package for the Social Sciences (SPSS for Windows). The following assumptions were made about the data: (1) all loci show complete dominance; (2) all loci have 2 alleles; (3) the marker alleles from different loci do not co-migrate to the same position on the gel; (4) all loci migrate according to Mendelian segregation; and (5) the populations are in Hardy-Weinberg Equilibrium (HWE) according to previous allozyme data (Apte \& Gardner 2001). Because dominant markers cannot verify HWE empirically, the percentage of absent bands at a locus gives the frequency of the recessive homozygote $\left(q^{2}\right)$. To reduce the bias associated with the analysis of dominant markers, a reduced data set was used in the population genetic analysis by pruning loci with lowrecessive allele frequencies where $q^{2}<3 / \mathrm{n}$, where $\mathrm{n}=$ number of individuals in the population (Lynch \& Milligan 1994).

Based on the results from previous mtDNA research (Apte \& Gardner 2002), the 19 populations were provisionally labeled either 'northern' (11 populations) or 'southern' (8 populations) for analysis (subsequent analysis of the RAPD data set confirmed this labeling see 'Results' section). The northern group consisted of all the North Island populations, as well as all the cultured populations originating from Kaitaia spat (HOU, TEK, KAT, BGB; see Fig. 1), and all the populations in the Cook Strait region. The southern group contained all other populations. The means, medians, interquartile ranges, and the range of the number of bands were calculated for all populations and separately for both groupings. Individuals with absent data were ignored to prevent large deviations. Dunnett's T3 test was used to test the null hypothesis that the mean number of bands per individual was not significantly different between all pairs of populations. Significance (p) values were corrected for multiple testing using the sequential Bonferroni technique (Holm 1979, Rice 1989). A Mann-Whitney $U$-test was used to test the null hypothesis that the mean number of bands was not significantly different between the northern and southern group. The number of different genotypes (based upon identical banding patterns) was assessed for each population and for both groups. A $2 \times 2$ contingency table analysis using the program $\mathrm{R} \times \mathrm{C}$ (M. Miller; available at http://bioweb.usu.edu/mpmbio) (1000 dememorization steps, 20 batches, 2500 replicates per batch) was performed to test the null hypothesis that the number of genotypes was not significantly different between the northern and the southern group. 
Allele frequencies were estimated based on the Taylor expansion (Lynch \& Milligan 1994). Allele frequencies were rounded to exactly match the observed samples. Exact tests (1000 dememorization steps, 10 batches, 2000 permutations per batch) were used to test the null hypothesis that allele frequencies were not significantly different between all possible pairs of populations (Sokal \& Rohlf 1995). A Markov Chain Monte Carlo approach was used to generate approximations of the exact probability of the observed differences in allele frequencies (Raymond \& Rousset 1995). Significance (p) values were corrected for multiple testing (see method above). Exact tests were also used to test the null hypothesis that allele frequencies were not significantly different between the northern and southern group.

A UPGMA analysis was carried out using the matrix of genetic distances estimated by Nei's method (Nei 1978). Confidence estimates for nodes in the tree were generated by bootstrapping across all loci. Wright's F-statistics, based upon ANOVA of weighted allele frequencies (Weir \& Cockerham 1984) were used to assess $\theta$ (among population component of total population genetic differentiation) for all populations $(n=19)$, and for the northern $(n=11)$ and southern $(n=8)$ populations. Mean estimates and standard errors were obtained by jackknifing over all 13 loci. The null hypothesis that $\theta$ is equal to 0 (i.e. no population genetic differentiation) was tested according to Waples (1987). Estimates of gene flow $\left(\mathrm{Nm}_{\theta}\right.$ : number of migrants per generation as calculated from theta) were calculated from $\theta$ according to $\mathrm{Nm}=0.25(1-\theta) / \theta$ (Slatkin \& Barton 1989).

\section{RESULTS}

Primers OPC-15, OPG-12 and OPI-04 produced 6, 11 and 4 bands respectively in the range of 700 to $2000 \mathrm{bp}$ that could be scored with confidence and accuracy (Fig. 2). Thus, in total 21 bands were scored for presence and absence. We assume that the vast majority of these bands are derived from the nuclear genome, but some small proportion could be derived from the mitochondrial genome. The medians and interquartile ranges of the number of bands from all populations did not show large differences (Fig. 3). Southern populations typically had a higher median, a larger interquartile range, and a larger total range than northern populations. No large differences were observed among mean number of bands per population (Table 2). After correction for multiple testing, Dunnett's T3 test identified significant differences between mean number of bands for the NMC and PAK populations $(\mathrm{p}<0.001)$. A significant difference in the mean number of bands per individual $(8.98 \pm 1.63$ in the northern group, $9.52 \pm 2.03$ in the southern group) was also observed between the 2 groups (MannWhitney $U$-test, $\mathrm{p}=0.001$ ).

A total of 347 unique genotypes was observed among 473 mussels. The number of genotypes per population was often equal to, or only slightly less than, the number of sampled individuals (Table 3). For the northern and southern groups the number of genotypes was $184(\mathrm{n}=267)$ and $173(\mathrm{n}=206)$, respectively, and there was no significant difference $(p=0.217)$ between the 2 groups in genotypic diversity as a function of total number of sampled mussels.

Thirteen loci had null phenotype frequencies above $3 / \mathrm{n}$ for all populations and these were used in the reduced dataset as recommended by Lynch \& Milligan (1994). No north-specific or south-specific alleles were found, but 16 of the 42 putative alleles were absent from at least one population (Table 4). After correction for multiple testing, significant differences in allele frequency were observed between pairwise comparisons of populations using exact tests for population differentiation (Table 5). There was a greater number of sig-

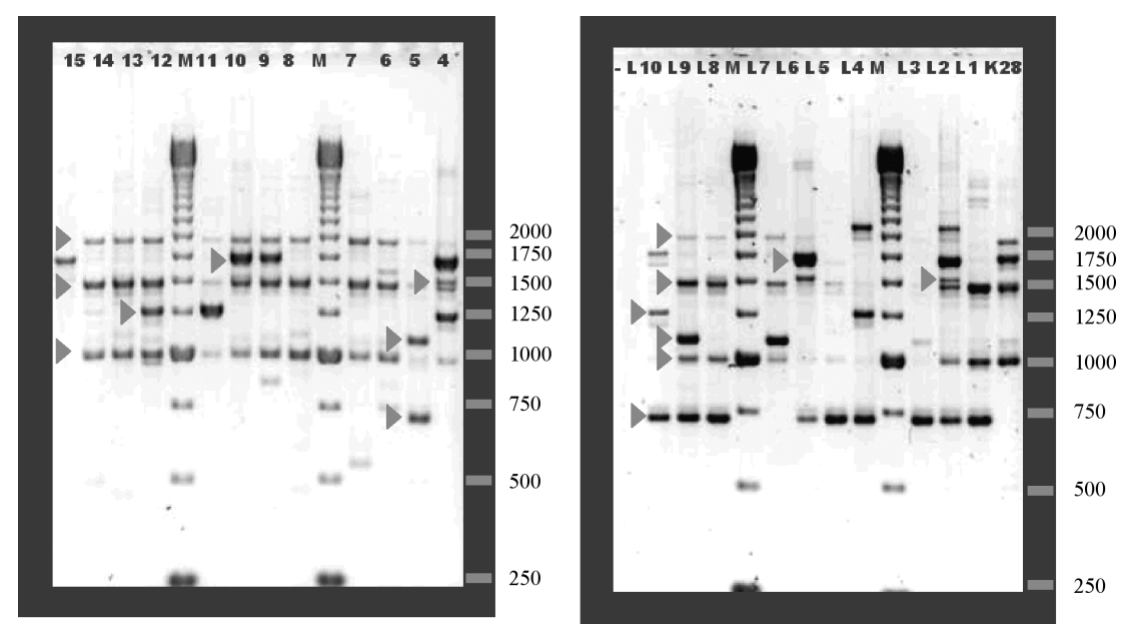

Fig. 2. Perna canaliculus. Banding patterns generated by primer OPG-12. The picture on the left shows the banding patterns of 12 individuals from the northern Kaitaia (KAT) population. The panel on the right shows the banding patterns of 10 individuals from the southern Little Wanganui River (LWR) population (indicated by L) and one individual of KAT (indicated by K) and a negative control (indicated by -). Lanes labeled $\mathrm{M}$ in both pictures contain the $250 \mathrm{bp}$ molecular marker; fragment sizes (bp) are indicated to the right of each gel. Arrows indicate easily scorable and/or partially diagnostic bands 


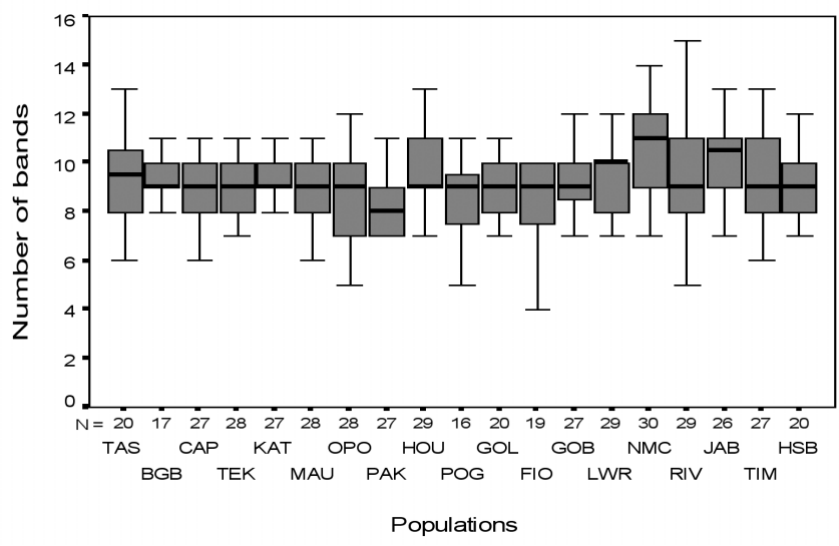

Fig. 3. Perna canaliculus. Number of bands per individual in the 19 populations. The box represents the interquartile range which contains $50 \%$ of the values. The whiskers symbolize the range, excluding outliers. The line across the box indicates the median. $\mathrm{N}$ = number of individuals per population

nificant differences in allele frequencies between the 4 west coast populations of the southern group (FIO, LWR, JAB, and NMC) and all 11 populations of the northern group, than between the other 4 populations (GOB, TIM, RIV, and HSB) of the southern group and the 11 populations of the northern group. The data were pooled into 2 large groups (11 northern and 8 southern populations, respectively), both of which had null genotype frequencies above $3 / n$ at all loci. The northern and southern groups were significantly different ( $p<0.0001)$, primarily as a consequence of allelic frequency differences at 5 loci (Fig. 4).

Genetic distances and identities between populations were calculated according to Nei (1978) (Table 6). UPGMA cluster analysis based on Nei's genetic distance estimates revealed a northern clade and a southern clade (Fig. 5). The southern clade contained all the South Island populations, except for HSB (Stewart Island), which falls into the northern clade where it is an outlier. No geographic structuring within the northern clade (excluding HSB) was evident. The smaller northern cluster contained 3 cultured populations (TEK, HOU and BGB) and 2 wild populations (POG and CAP), while the larger cluster contained 2 cultured populations (GOL and KAT), and 4 wild populations (TAS, OPO, PAK and MAU). Within the southern clade, a west coast cluster (containing FIO, JAB, LWR and NMC) was separated from 2 east coast populations (TIM and GOB) and 1 southern population (RIV). Every attempt to generate bootstrap values to estimate node support resulted in trees containing ties, therefore we could not determine the degree of confidence for the topology of this tree (Backeljau et al. 1996).

There was highly significant population differentiation among all 19 populations studied (Table 7). Among the 11 northern populations there was no significant population differentiation ( $p>0.05)$, but when the HSB population was included in the northern group then significant population differentiation was observed ( $p=0.025)$. Among the 8 southern populations there was significant population differentiation $(\mathrm{p}<0.0001)$; however, this was due solely to the presence of the HSB population in the southern group $(\mathrm{p}>0.05$ when HSB was removed from this group). Estimates of gene flow (number of migrants per generation) were lowest among all 19 populations, higher among the 8 southern populations, and highest among the 11 northern populations (Table 8). Estimates of gene flow were reduced in the north and south groups upon inclusion of the HSB population. In all cases, estimates of gene flow were $>1.0$, and were often very high (>10 migrants per generation).

\section{DISCUSSION}

Three specifically selected RAPD primers that yielded 21 putative loci were used in this study to assess genetic structuring among 19 populations of the

Table 2. Perna canaliculus. Average number of bands scored per individual in each population. ${ }^{\mathrm{n}}=$ northern $_{\text {group }} \mathrm{i}_{\mathrm{s}}=$ southern group. See Table 1 for abbreviations

\begin{tabular}{|c|c|c|c|c|c|c|c|c|c|c|c|c|c|c|c|c|c|c|}
\hline & $\mathrm{TAS}^{\mathrm{n}}$ & $\mathrm{BGB}^{\mathrm{n}}$ & $\mathrm{CAP}^{\mathrm{n}}$ & $\mathrm{TEK}^{\mathrm{n}}$ & $\mathrm{KAT}^{\mathrm{n}}$ & $\mathrm{MAU}^{\mathrm{n}}$ & $\mathrm{OPO}^{\mathrm{n}}$ & $\mathrm{PAK}^{\mathrm{n}}$ & $\mathrm{HOU}^{\mathrm{n}}$ & $\mathrm{POG}^{\mathrm{n}}$ & $\mathrm{GOL}^{\mathrm{n}}$ & $\mathrm{FIO}_{\mathrm{s}}$ & $\mathrm{GOB}_{\mathrm{s}}$ & $\mathrm{LWR}_{\mathrm{s}}$ & $\mathrm{NMC}_{\mathrm{s}}$ & $\mathrm{RIV}_{\mathrm{s}} \mathrm{JAB}_{\mathrm{s}}$ & $\mathrm{TIM}_{\mathrm{s}}$ & $\mathrm{HSB}_{\mathrm{s}}$ \\
\hline Mean & 9.25 & 9.52 & 9.07 & 8.93 & 9.41 & 8.96 & 8.89 & 7.89 & 9.48 & 8.31 & 9 & 8.63 & 9.19 & 9.41 & 10.53 & 9.2310 .15 & 9.48 & 8.85 \\
\hline $\mathrm{SD}$ & 1.86 & 1.55 & 1.64 & 1.65 & 1.08 & 1.45 & 1.83 & 1.50 & 1.75 & 1.99 & 1.08 & 2.00 & 1.42 & 1.97 & 1.52 & $2.35 \quad 2.20$ & 2.93 & 1.84 \\
\hline
\end{tabular}

Table 3. Perna canaliculus. Number of genotypes per population. SS is the sample size. H is the number of genotypes. ${ }^{\mathrm{n}}=$ northern group $_{\text {s }}=$ southern group. See Table 1 for abbreviations

\begin{tabular}{|lccccccccccccccccccc}
\hline & TAS $^{n}$ & BGB $^{n}$ & CAP $^{\mathrm{n}}$ & TEK $^{\mathrm{n}}$ & KAT $^{\mathrm{n}}$ & MAU $^{\mathrm{n}}$ & OPO $^{\mathrm{n}}$ & PAK $^{\mathrm{n}}$ & HOU $^{\mathrm{n}}$ & POG $^{\mathrm{n}}$ & GOL $^{\mathrm{n}}$ & FIO $_{\mathrm{s}}$ & GOB $_{\mathrm{s}}$ & LWR $_{\mathrm{s}}$ & NMC $_{\mathrm{s}}$ & RIV $_{\mathrm{s}}$ & JAB $_{\mathrm{s}}$ & TIM $_{\mathrm{s}}$ & HSB $_{\mathrm{s}}$ \\
\hline $\mathrm{SS}$ & 20 & 17 & 27 & 28 & 27 & 28 & 28 & 27 & 29 & 16 & 20 & 19 & 27 & 29 & 30 & 28 & 26 & 27 & 20 \\
$\mathrm{H}$ & 20 & 17 & 25 & 26 & 22 & 25 & 24 & 27 & 28 & 15 & 17 & 17 & 22 & 27 & 30 & 28 & 25 & 27 & 20 \\
\hline
\end{tabular}


Table 4. Perna canaliculus. Allele frequency estimates based on Lynch \& Milligan's (1994) Taylor expansion estimate (allele frequencies rounded to exactly match observed sample). ' $a$ ' represents the dominant allele (1) whereas 'b' represents the recessive allele (0). ${ }^{n}=$ northern $_{\text {group }}$ s $_{\mathrm{s}}=$ the southern group. See Table 1 for abbreviations

\begin{tabular}{|c|c|c|c|c|c|c|c|c|c|c|c|c|c|c|c|c|c|c|c|c|}
\hline Allele & & TAS $^{\mathrm{n}}$ & $\mathrm{BGB}^{\mathrm{n}}$ & $\mathrm{CAP}^{\mathrm{n}}$ & $\mathrm{TEK}^{\mathrm{n}}$ & $\mathrm{KAT}^{\mathrm{n}}$ & $\mathrm{MAU}^{\mathrm{n}}$ & $\mathrm{OPO}^{\mathrm{n}}$ & $\mathrm{PAK}^{\mathrm{n}}$ & $\mathrm{HOU}^{\mathrm{n}}$ & $\mathrm{POG}^{\mathrm{n}}$ & $\mathrm{GOL}^{\mathrm{n}}$ & $\mathrm{FIO}_{\mathrm{s}}$ & c & $\mathrm{LWR}_{\mathrm{s}}$ & $\mathrm{NMC}_{\mathrm{s}}$ & $\mathrm{RIV}_{\mathrm{s}}$ & $\mathrm{JAB}_{\mathrm{s}}$ & $\mathrm{TIM}_{\mathrm{s}}$ & 1 \\
\hline \multirow[t]{2}{*}{ C15-1 } & $\mathrm{a}$ & 0.00 & 0.03 & 0.02 & 0.02 & 0.02 & 0.00 & 0.00 & 0.02 & 0.02 & 0.00 & 0.00 & 0.39 & 0.33 & 0.33 & 0.32 & 0.32 & 0.35 & 0.28 & 0.30 \\
\hline & b & 1.00 & 0.97 & 0.98 & 0.98 & 0.98 & 1.00 & 1.00 & 0.98 & 0.98 & 1.00 & 1.00 & 0.61 & 0.67 & 0.67 & 0.68 & 0.68 & 0.65 & 0.69 & 0.70 \\
\hline \multirow[t]{2}{*}{ C15-2 } & $\mathrm{a}$ & 0.00 & 0.11 & 0.05 & 0.02 & 0.05 & 0.02 & 0.02 & 0.07 & 0.03 & 0.03 & 0.00 & 0.08 & 0.00 & 0.05 & 0.08 & 0.10 & 0.04 & 0.06 & 0.05 \\
\hline & $\mathrm{b}$ & 1.00 & 0.89 & 0.95 & 0.98 & 0.95 & 0.98 & 0.98 & 0.93 & 0.97 & 0.98 & 1.00 & 0.92 & 1.00 & 0.95 & 0.92 & 0.87 & 0.96 & 0.94 & 0.95 \\
\hline \multirow[t]{2}{*}{$\mathrm{C} 15-3^{\mathrm{a}}$} & $\mathrm{a}$ & 0.75 & 0.61 & 0.68 & 0.70 & 0.66 & 0.79 & 0.66 & 0.45 & 0.72 & 0.60 & 1.00 & 0.45 & 1.00 & 0.67 & 0.48 & 0.55 & 0.56 & 0.54 & 0.68 \\
\hline & $\mathrm{b}$ & 0.25 & 0.39 & 0.32 & 0.27 & 0.34 & 0.21 & 0.34 & 0.55 & 0.28 & 0.40 & 0.00 & 0.50 & 0.00 & 0.33 & 0.52 & 0.45 & 0.44 & 0.43 & 0.32 \\
\hline \multirow[t]{2}{*}{ C15-4 } & a & 0.00 & 0.03 & 0.05 & 0.00 & 0.04 & 0.02 & 0.00 & 0.07 & 0.00 & 0.03 & 0.00 & 0.05 & 0.00 & 0.03 & 0.05 & 0.08 & 0.02 & 0.02 & 0.00 \\
\hline & b & 1.00 & 0.97 & 0.95 & 1.00 & 0.96 & 0.98 & 1.00 & 0.93 & 1.00 & 0.98 & 1.00 & 0.95 & 1.00 & 0.97 & 0.95 & 0.92 & 0.98 & 0.98 & 1.00 \\
\hline \multirow[t]{2}{*}{ C15-5 } & $\mathrm{a}$ & 0.00 & 0.08 & 0.02 & 0.00 & 0.00 & 0.00 & 0.02 & 0.02 & 0.02 & 0.00 & 0.03 & 0.18 & 0.01 & 10 & 0.25 & 0.08 & 0.27 & .02 & .18 \\
\hline & b & 1.00 & 0.92 & 0.98 & 1.00 & 1.00 & 1.00 & 0.98 & 0.98 & 0.98 & 1.00 & 0.98 & 0.82 & 0.99 & 0.90 & 0.75 & 0.92 & 0.73 & .98 & 0.82 \\
\hline \multirow{2}{*}{$\mathrm{C} 15-6^{\mathrm{a}}$} & $\mathrm{a}$ & 1.00 & 0.71 & 1.00 & 1.00 & 1.00 & 1.00 & 0.77 & 1.00 & 1.00 & 1.00 & 1.00 & 0.71 & 1.00 & 0.79 & 1.00 & 1.00 & 0.79 & 0.76 & 1.00 \\
\hline & $\mathrm{b}$ & 0.00 & 0.24 & 0.00 & 0.00 & 0.00 & 0.00 & 0.20 & 0.00 & 0.00 & 0.00 & 0.00 & 0.24 & 0.00 & 0.21 & 0.00 & 0.00 & 0.21 & 0.20 & 0.00 \\
\hline \multirow[t]{2}{*}{ G12-1 } & $\mathrm{a}$ & 0.20 & 0.05 & 0.17 & 0.09 & 0.02 & 0.04 & 0.03 & 0.02 & 0.09 & 0.00 & 0.03 & 0.68 & 0.59 & 0.62 & 0.73 & 0.45 & 0.59 & 0.43 & 0.23 \\
\hline & b & 0.80 & 0.95 & 0.83 & 0.91 & 0.98 & 0.96 & 0.97 & 0.9 & & 1.00 & 0.98 & 0.33 & 0.38 & 0.38 & 0.27 & 0.55 & 0.38 & 57 & 0.77 \\
\hline \multirow[t]{2}{*}{ G12-2 } & a & 0.13 & .08 & 0.10 & 0.04 & 0.0 & 0.0 & 0.02 & 0. & 0 . & 0. & 0.00 & 0.00 & 0. & 3 & 0.05 & 0.03 & 0.04 & .07 & 0.02 \\
\hline & $\mathrm{b}$ & 0.88 & 0.92 & 0.87 & 0.96 & 0.9 & 0.9 & 0.98 & & & 0.94 & 1.00 & 1.00 & 1.00 & & 0.95 & 0.97 & 0.96 & .93 & 0.98 \\
\hline \multirow[t]{2}{*}{ G12-3 } & $\mathrm{a}$ & 0.45 & 0.50 & 0.55 & 0.50 & 0.70 & & 0.5 & & & 0.44 & & 0.13 & 0.34 & & & 0.40 & 0.50 & 1 & .36 \\
\hline & $\mathrm{b}$ & 0.55 & 0.45 & 0.45 & 0.50 & 0.27 & 0.54 & 0.41 & 0. & 0. & 0.56 & 0.25 & 0.88 & 0.66 & 9 & 0.00 & 0.60 & 0.50 & 39 & .64 \\
\hline \multirow[t]{2}{*}{ G12-4 } & a & 0.05 & 0.08 & 0.03 & 0.02 & 0.02 & 0.04 & 0.00 & 0.05 & 0.10 & 0.00 & 0.03 & 0.00 & 0.00 & 0.03 & 0.05 & 0.07 & 0.04 & 0.07 & 0.02 \\
\hline & $\mathrm{b}$ & 0.95 & 0.92 & 097 & 0.98 & 0.98 & 0.96 & 1.00 & & & 1.00 & & 1.00 & 1.00 & & 0.95 & 0.93 & 0.96 & 0.93 & 0.98 \\
\hline \multirow[t]{2}{*}{ G12-5 } & $\mathrm{a}$ & 0.08 & 0.08 & .00 & & 0.0 & 0.0 & & & & 0. & 0. & 0.03 & 0. & 9 & 0 & 0.05 & 0.09 & 17 & 0.05 \\
\hline & $\mathrm{b}$ & 0.93 & 0.92 & 1.00 & 0.86 & 0.9 & 0.98 & 0.8 & 0. & 0.8 & 1.0 & 0.95 & 0.98 & 0.95 & 0.91 & 0.93 & 0.95 & 0.91 & 0.83 & 0.95 \\
\hline \multirow[t]{2}{*}{ G12-6 } & $\mathrm{a}$ & 0.10 & 0.21 & 0.18 & 0.21 & 0.21 & 0.16 & 0.2 & 0.21 & 0.10 & 0.09 & 0.08 & 0.08 & 0.11 & 10 & 0.15 & 0.17 & 0.16 & .17 & 0.23 \\
\hline & $\mathrm{b}$ & 0.90 & 0.79 & 0.82 & 0.79 & 0.79 & 0.84 & 0.79 & 0.79 & 0.86 & 0.91 & 0.93 & 0.93 & 0.89 & 0.86 & 0.85 & 0.83 & 0.84 & 0.83 & 0.77 \\
\hline \multirow[t]{2}{*}{ G12-7 } & $\mathrm{a}$ & 0.60 & 0.61 & 0.68 & 0.77 & 0.77 & 0.66 & 0.59 & 0.38 & 0.79 & 0.50 & 0.75 & 0.33 & 0.34 & 0.59 & 1.00 & 0.52 & 0.50 & 0.72 & 0.48 \\
\hline & $\mathrm{b}$ & 0.40 & 0.39 & 0.32 & 0.20 & 0.20 & 0.34 & 0.41 & 0.5 & 0.21 & 0.50 & 0.25 & 0.68 & 0.66 & 0.41 & 0.00 & 0.48 & 0.50 & 0.28 & 0.52 \\
\hline \multirow[t]{2}{*}{ G12-8 } & a & 0.13 & 0.18 & 0.20 & 0. & 0. & & 0. & & & 0. & & 0.20 & 0. & & 0. & 0.10 & 0.18 & 0.09 & 0.18 \\
\hline & $\mathrm{b}$ & 0.88 & 0.82 & 07 & 0. & 0.8 & 0. & 0.7 & 0 & 0. & 08 & 0. & 0.80 & 0.7 & 3 & 0.92 & 0.87 & 0.82 & 0.91 & 0.82 \\
\hline \multirow[t]{2}{*}{ G12-9 } & $\mathrm{a}$ & 0.23 & 0.24 & 0.20 & 0.25 & 0.2 & 0. & 0 & & 0.2 & 0.3 & 0.20 & 0.25 & 0.2 & 9 & 0.10 & 0.18 & 0.21 & 0.19 & 0.23 \\
\hline & $\mathrm{b}$ & 0.78 & 0.71 & 0.77 & 0.75 & 0.79 & 0.82 & 0.76 & 0.82 & 0.74 & 0.63 & 0.80 & 0.75 & 0.73 & 0.91 & 0.87 & 0.82 & 0.79 & 0.81 & 0.77 \\
\hline \multirow[t]{2}{*}{ G12-10 } & a & 0.03 & 0.03 & 0.05 & 0.02 & 0.02 & 0.04 & 0.03 & 0.02 & 0.02 & 0.06 & 0.05 & 0.03 & 0.00 & 0.03 & 0.02 & 0.02 & 0.00 & 0.04 & 0.05 \\
\hline & b & 0.98 & 0.97 & 0.95 & 0.98 & 0.98 & 0.96 & 0.97 & 0.9 & 0.98 & 0.94 & 0.95 & 0.98 & 1.00 & 0.97 & 0.98 & 0.98 & 1.00 & 0.96 & 0.95 \\
\hline \multirow[t]{2}{*}{ G12-11 } & ${ }^{a} a$ & 0.50 & 0.45 & 0.52 & 0.66 & 0.57 & 0.70 & 0.52 & 0.34 & 0.79 & 0.38 & 1.00 & 0.08 & 0.09 & 0.19 & 0.30 & 0.10 & 0.25 & 0.04 & 0.20 \\
\hline & $\mathrm{b}$ & 0.50 & 0.55 & $0.4 \varepsilon$ & & 0.4 & 0.27 & 0.4 & 0.6 & 0.2 & 0.6 & 0.00 & 0.93 & 0.91 & 081 & 0.70 & 0.87 & 0.75 & 0.96 & 0.80 \\
\hline I04-1 & a & 0.33 & 0.10 & 0.0 & 0.1 & 0.2 & $0=$ & 0.3 & 0. & 0 . & 01 & 0.23 & 0.13 & 0.28 & 0.10 & 0.37 & 0.21 & 0.16 & 0.28 & 0.03 \\
\hline & $\mathrm{b}$ & 0.68 & 0.90 & 0.91 & 0.82 & 0.69 & 0.69 & 0.67 & 0.74 & 0.86 & 0.90 & 0.78 & 0.88 & 0.72 & 0.87 & 0.63 & 0.79 & 0.84 & 0.72 & 0.98 \\
\hline $\mathrm{I} 04-2^{\mathrm{a}}$ & $\mathrm{a}$ & 1.00 & 0.69 & 0.59 & 0.66 & 1.00 & 0.72 & 0.67 & 0.45 & 0.72 & 1.00 & 0.75 & 1.00 & 1.00 & 0.73 & 0.55 & 0.66 & 0.66 & 0.67 & 0.75 \\
\hline & b & 0.00 & 0.31 & 0.38 & 0.34 & 0.00 & 0.28 & 0.33 & 0.52 & 0.28 & 0.00 & 0.25 & 0.00 & 0.00 & 0.27 & 0.45 & 0.34 & 0.34 & 0.33 & 0.25 \\
\hline $\mathrm{I} 04-3^{\mathrm{a}}$ & $\mathrm{a}$ & 0.68 & 0.62 & 0.32 & 0.38 & 1.00 & 0.72 & 0.38 & 0.33 & 0.72 & 0.40 & 0.60 & 0.50 & 0.67 & 0.58 & 0.63 & 0.66 & 0.77 & 0.67 & 0.45 \\
\hline & $\mathrm{b}$ & 0.33 & 0.38 & 0.68 & 0.59 & 0.00 & 0.28 & 0.62 & 0.6 & 0.28 & 0.60 & 0.40 & 0.50 & 0.33 & 0.42 & 0.37 & 0.34 & 0.20 & 0.33 & 0.55 \\
\hline $\mathrm{I} 04-4^{\mathrm{a}}$ & $\mathrm{a}$ & 0.55 & 0.52 & 0.5 & & 0.5 & & & & & & 0.55 & 0.45 & 0.61 & 0.73 & 0.58 & 0.57 & 0.66 & 0.46 & 0.45 \\
\hline & $\mathrm{b}$ & 0.45 & 0.43 & 0.38 & 0.34 & 0.46 & 0.48 & 0.38 & 0.45 & 0.55 & 0.50 & 0.45 & 0.55 & 0.39 & 0.27 & 0.42 & 0.43 & 0.34 & 0.50 & 0.55 \\
\hline
\end{tabular}

endemic New Zealand greenshell mussel Perna canaliculus. Five loci with significantly different allele frequencies between pooled northern and southern populations were identified. The subdivision of the 19 populations into 2 distinct groups is supported by the different statistical approaches used in this work. For example, reduction of the number of loci on a population-specific basis (following Lynch \& Milligan 1994) resulted in 13 loci for analysis. While we did not observe any group-specific alleles, 5 alleles exhibited significantly different frequencies between northern and southern populations, and the frequency of 2 of these alleles was very low (0.01 and 0.06, respectively) in the northern group, but moderately high (0.32 and
0.55) in the southern group. Thus, we observed a pronounced population genetic subdivision among populations of a species that is continuously distributed throughout 12 degrees of latitude in New Zealand.

One of the primary aims of this study was to compare RAPD population genetic variation in Perna canaliculus with the same individuals from the mtDNA SSCP analysis (Apte \& Gardner 2002). The results of these 2 studies show a high degree of concordance. First, nonsignificant differences in RAPD allele frequencies were found in the pairwise comparisons between populations within the northern group and between populations within the southern group, while highly significant pairwise differences in allele frequencies 
Table 5. Perna canaliculus. Pairwise exact tests of population differentiation (Sokal \& Rohlf 1995). After correction for multiple testing with the sequential Bonferroni technique, $p$ values are still significant (values in bold are significant at p < 0.00034) (Holm 1979, Rice 1989). ${ }^{\mathrm{n}}=$ northern group $_{\mathrm{s}}=$ southern group. See Table 1 for abbreviations

\begin{tabular}{|c|c|c|c|c|c|c|c|c|c|c|c|c|c|c|c|c|c|c|}
\hline & $\mathrm{TAS}^{\mathrm{n}}$ & $\mathrm{BGB}^{\mathrm{n}}$ & $\mathrm{CAP}^{\mathrm{n}}$ & $\mathrm{TEK}^{\mathrm{n}}$ & $\mathrm{KAT}^{\mathrm{n}}$ & $\mathrm{MAU}^{\mathrm{n}}$ & $\mathrm{OPO}^{\mathrm{n}}$ & $\mathrm{PAK}^{\mathrm{n}}$ & $\mathrm{HOU}^{\mathrm{n}}$ & $\mathrm{POG}^{\mathrm{n}}$ & $\mathrm{GOL}^{\mathrm{n}}$ & $\mathrm{FIO}_{\mathrm{s}}$ & $\mathrm{GOB}_{\mathrm{s}}$ & $\mathrm{LWR}_{\mathrm{s}}$ & $\mathrm{NMC}_{\mathrm{s}}$ & $\mathrm{RIV}_{\mathrm{s}} \quad \mathrm{JAB}_{\mathrm{s}}$ & $\mathrm{TIM}_{\mathrm{s}}$ & $\mathrm{HSB}_{\mathrm{s}}$ \\
\hline $\mathrm{TAS}^{\mathrm{n}}$ & ..... & & & & & & & & & & & & & & & & & \\
\hline $\mathrm{BGB}^{\mathrm{n}}$ & 0.2734 & $\cdots \cdots$ & & & & & & & & & & & & & & & & \\
\hline $\mathrm{CAP}^{\mathrm{n}}$ & 0.5176 & 0.8914 & $\cdots \cdots$ & & & & & & & & & & & & & & & \\
\hline TEK $^{\mathrm{n}}$ & 0.8735 & 0.677 & 0.2922 & $\cdots * *$ & & & & & & & & & & & & & & \\
\hline $\mathrm{KAT}^{\mathrm{n}}$ & 0.4978 & 0.5766 & 0.3277 & 0.9529 & $\ldots \ldots$ & & & & & & & & & & & & & \\
\hline $\mathrm{MAU}^{\mathrm{n}}$ & 0.975 & 0.3042 & 0.4344 & 0.9615 & 1 & ..... & & & & & & & & & & & & \\
\hline $\mathrm{OPO}^{\mathrm{n}}$ & 0.5448 & 0.3077 & 0.0249 & 0.9794 & 0.9527 & 0.8543 & $\ldots \ldots$ & & & & & & & & & & & \\
\hline $\mathrm{PAK}^{\mathrm{n}}$ & 0.3807 & 0.8979 & 0.2152 & 0.9384 & 1 & 0.9999 & 0.5859 & ..... & & & & & & & & & & \\
\hline $\mathrm{HOU}^{\mathrm{n}}$ & 0.9478 & 0.9891 & 0.3366 & 0.9966 & 0.2689 & 0.7431 & 0.6167 & 0.6115 & $\cdots \cdots$ & & & & & & & & & \\
\hline $\mathrm{POG}^{\mathrm{n}}$ & 0.523 & 0.711 & 0.8841 & 0.6491 & 0.8919 & 0.8878 & 0.4025 & 0.5917 & 0.6546 & $\cdots \cdots$ & & & & & & & & \\
\hline $\mathrm{GOL}^{\mathrm{n}}$ & 0.9755 & 0.3126 & 0.1796 & 0.9543 & 0.953 & 0.9991 & 0.9702 & 0.8345 & 0.7459 & 0.9947 & $\cdots \cdots$ & & & & & & & \\
\hline $\mathrm{FIO}_{\mathrm{s}}$ & 0 & 0.0013 & 0.0001 & 0 & 0 & 0 & $\mathbf{0}$ & 0 & 0 & 0.0002 & 0.0006 & $\cdots \cdots$ & & & & & & \\
\hline $\mathrm{GOB}_{\mathrm{s}}$ & 0.0026 & 0 & 0 & 0.001 & 0.0007 & 0.0021 & 0.0022 & 0 & 0 & 0.0001 & 0.0023 & 0.279 & $\cdots \cdots$ & & & & & \\
\hline $\mathrm{LWR}_{\mathrm{s}}$ & 0.0002 & 0.003 & 0 & 0.0001 & 0 & 0.0001 & 0 & 0.0003 & 0.0002 & 0 & 0.0003 & 0.8232 & 0.084 & ....* & & & & \\
\hline $\mathrm{NMC}_{\mathrm{s}}$ & 0 & 0.0001 & 0 & 0 & 0.0001 & 0 & 0 & 0.0001 & 0 & 0 & 0 & 0.5312 & 0.0046 & 0.869 & 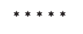 & & & \\
\hline RIV $_{s}$ & 0.0011 & 0.0087 & 0.001 & 0.0001 & 0.0006 & 0.0002 & 0 & 0.0054 & 0 & 0 & 0.0002 & 0.7179 & 0.079 & 0.8549 & 0.8549 & $\cdots * *$ & & \\
\hline $\mathrm{JAB}_{\mathrm{s}}$ & 0.0001 & 0.0012 & 0 & 0 & 0 & 0 & 0 & 0 & $\mathbf{0}$ & 0 & 0.0001 & 0.9763 & 0.1663 & 0.9144 & 0.8359 & $0.6188 \cdots \cdots *$ & & \\
\hline $\mathrm{TIM}_{\mathrm{s}}$ & 0.0974 & 0.0086 & 0.0001 & 0.0011 & 0.0003 & 0.0008 & 0.0002 & 0.0059 & 0.0081 & 0 & 0.0006 & 0.0366 & 0.0608 & 0.5427 & 0.1589 & $0.8704 \quad 0.0463$ & $\cdots \cdots *$ & \\
\hline $\mathrm{HSB}_{\mathrm{s}}$ & 0.0013 & 0.1697 & 0.0119 & 0.0148 & 0.0002 & 0.0001 & 0.0001 & 0.0001 & 0.0017 & 0.0052 & 0.0114 & 0.4511 & 0.0006 & 0.0971 & 0.0009 & 0.20410 .3977 & 0.0548 & $\cdots \cdots$ \\
\hline
\end{tabular}

occurred between northern versus southern populations. These RAPD data emphasize the relative genetic uniformity within the 2 groups, as well as the genetic differentiation between them, and are in accord with our mtDNA SSCP study, which also reported nonsignificant haplotypic diversity estimates within each group, but significant differences between populations from the 2 groups (Apte \& Gardner 2002). The occurrence of a north-south split was, however, more pronounced for the RAPD markers, for which 59 of 88 $(67 \%)$ pairwise comparisons between northern and southern populations were statistically significant after correction for multiple testing, whereas 14 of 112

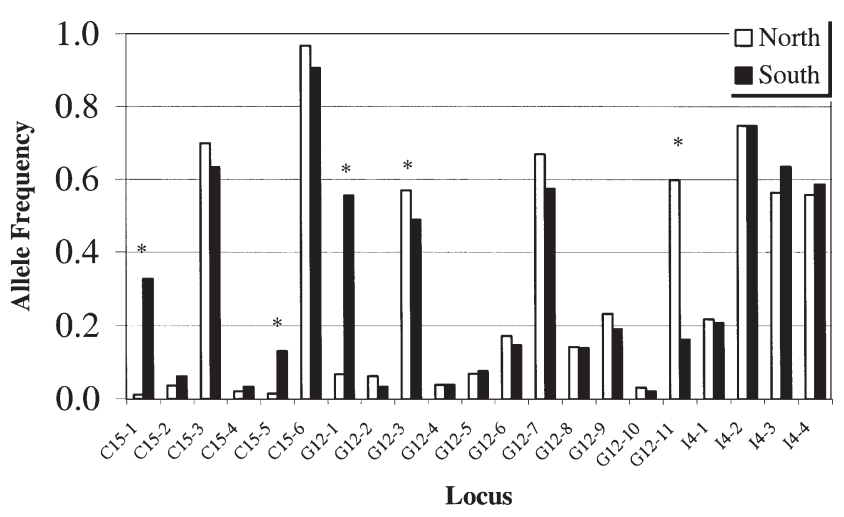

Fig. 4. Perna canaliculus. Differences in allele frequencies between pooled north and south populations. Only the frequencies of the dominant allele are shown. Plotted along the $x$-axis are the different loci, originating from the 3 different primers. * Significantly different after correction for multiple testing with the sequential Bonferroni technique
$(12.5 \%)$ pairwise comparisons between northern and southern populations were statistically significant after correction for multiple testing in the mtDNA SSCP study (Apte \& Gardner 2002). Second, the analysis of RAPD markers showed that the 4 west coast populations of the southern group were more distinct from the northern populations than are the other populations of the southern group. For example, 40 of 59 (68\%) significant values were observed between the 4 western populations of the southern group and populations from the northern group (see Table 4). A similar, but more pronounced, outcome was observed for the mtDNA SSCP study, in which 13 of 14 (93\%) significant values were observed between west coast populations of the southern group and the northern group (Apte \& Gardner 2002). Third, higher RAPD diversity was observed among the southern populations than among the northern populations. Pooled populations from the southern group had significantly higher mean numbers of bands per individual than pooled populations from the northern group; however, the absolute difference between the means was not significant. The fact that the populations did not differ much in actual mean number of bands was also observed in the pairwise comparison of means, which showed no significant differences among populations except between NMC and KAT (Table 6). The range of the number of bands per individual was higher in the southern group than in the northern group. RAPD genotypic diversity, which was high in both groups, was slightly higher in populations from the southern group, although this difference was not statistically significant. Nei's genetic distance estimates (1978) were also higher for RAPDs 
Table 6. Perna canaliculus. Nei's unbiased (1978) distance (below the diagonal) and identity (above the diagonal) between populations. ${ }^{\mathrm{n}}=$ northern group $_{\mathrm{s}}=$ southern group. See Table 1 for abbreviations

\begin{tabular}{|c|c|c|c|c|c|c|c|c|c|c|c|c|c|c|c|c|c|c|c|}
\hline & $\mathrm{TAS}^{\mathrm{n}}$ & $\mathrm{BGB}^{\mathrm{n}}$ & $\mathrm{CAP}^{\mathrm{n}}$ & $\mathrm{TEK}^{\mathrm{n}}$ & $\mathrm{KAT}^{\mathrm{n}}$ & $M A U^{\mathrm{n}}$ & $\mathrm{OPO}^{\mathrm{n}}$ & $\mathrm{PAK}^{\mathrm{n}}$ & $\mathrm{HOU}^{\mathrm{n}}$ & $\mathrm{POG}^{\mathrm{n}}$ & $\mathrm{GOL}^{\mathrm{n}}$ & $\mathrm{FIO}_{\mathrm{s}}$ & $\mathrm{GOB}_{\mathrm{s}}$ & $\mathrm{LWR}_{\mathrm{s}}$ & $\mathrm{NMC}_{\mathrm{s}}$ & $\mathrm{RIV}_{\mathrm{s}}$ & $\mathrm{JAB}_{\mathrm{s}}$ & $\mathrm{TIM}_{\mathrm{s}}$ & $\mathrm{HSB}_{\mathrm{s}}$ \\
\hline TAS $^{\mathrm{n}}$ & $* * * *$ & 0.9947 & 0.9962 & 0.9983 & 0.998 & 1.000 & 0.9978 & 0.9974 & 0.9976 & 0.993 & 0.9989 & 0.9598 & 0.9762 & 0.9697 & 0.9599 & 0.985 & 0.9676 & 0.9903 & 0.9824 \\
\hline $\mathrm{BGB}^{\mathrm{n}}$ & 0.0053 & $* * * * *$ & 1.0012 & 1.0008 & 0.9982 & 0.997 & 0.9967 & 0.9992 & 1.0016 & 1.0002 & 0.9989 & 0.9519 & 0.9601 & 0.9601 & 0.9392 & 0.9791 & 0.9611 & 0.9793 & 0.9931 \\
\hline $\mathrm{CAP}^{\mathrm{n}}$ & 0.0038 & -0.0012 & $* * * * *$ & 0.9977 & 0.9953 & 0.9953 & 0.9927 & 0.9956 & 0.9981 & 0.9977 & 0.9965 & 0.9616 & 0.97 & 0.9691 & 0.9489 & 0.9838 & 0.9674 & 0.9829 & 0.9923 \\
\hline TEK $^{\mathrm{n}}$ & 0.0017 & -0.0008 & 0.0023 & $* * * * *$ & 0.9997 & 0.999 & 0.9993 & 1.0001 & 1.0008 & 0.9974 & 0.9997 & 0.9522 & 0.9662 & 0.9639 & 0.9453 & 0.9808 & 0.9618 & 0.9851 & 0.9889 \\
\hline $\mathrm{KAT}^{\mathrm{n}}$ & 0.0020 & 0.0018 & 0.0047 & 0.0003 & $* * * *$ & 1.002 & 0.9999 & 1.0021 & 0.9962 & 0.9958 & 1.0001 & 0.9434 & 0.9601 & 0.9548 & 0.9406 & 0.9769 & 0.9529 & 0.9796 & 0.9829 \\
\hline$M^{\prime} U^{n}$ & 0.0000 & 0.003 & 0.0047 & 0.001 & -0.002 & $* * * *$ & 0.9995 & 1.0015 & 0.9965 & 0.995 & 1.001 & 0.9445 & 0.9616 & 0.9568 & 0.9433 & 0.9771 & 0.954 & 0.9808 & 0.9815 \\
\hline $\mathrm{OPO}^{\mathrm{n}}$ & 0.0022 & 0.0033 & 0.0073 & 0.0007 & 0.0001 & 0.0005 & $\cdots * *$ & 0.9986 & 0.9961 & 0.9936 & 0.9991 & 0.9419 & 0.961 & 0.9516 & 0.9387 & 0.9731 & 0.9529 & 0.9794 & 0.9806 \\
\hline $\mathrm{PAK}^{\mathrm{n}}$ & 0.0026 & 0.0008 & 0.0044 & -0.0001 & -0.0021 & 0.0015 & 0.0014 & $* * * * *$ & 0.9976 & 0.9949 & 0.9999 & 0.943 & 0.9578 & 0.9568 & 0.9412 & 0.9777 & 0.9534 & 0.9804 & 0.9837 \\
\hline $\mathrm{HOU}^{\mathrm{n}}$ & 0.0024 & -0.0016 & 0.0019 & -0.0008 & 0.0039 & 0.0035 & 0.0039 & 0.0024 & $\cdots * * *$ & 0.9984 & 0.9993 & 0.9519 & 0.9635 & 0.9631 & 0.9415 & 0.979 & 0.9608 & 0.9832 & 0.9883 \\
\hline $\mathrm{POG}^{\mathrm{n}}$ & 0.0070 & -0.0002 & 0.0023 & 0.0026 & 0.0042 & 0.005 & 0.0065 & 0.0051 & 0.0016 & $* * * * *$ & 0.9985 & 0.9447 & 0.9562 & 0.9496 & 0.9264 & 0.9706 & 0.9501 & 0.9712 & 0.9853 \\
\hline $\mathrm{GOL}^{\mathrm{n}}$ & 0.0011 & 0.0011 & 0.0035 & 0.0003 & -0.0001 & -0.001 & 0.0009 & 0.0001 & 0.0007 & 0.0015 & $* * * * *$ & 0.9486 & 0.9625 & 0.9589 & 0.9415 & 0.9772 & 0.9567 & 0.9802 & 0.9853 \\
\hline $\mathrm{FIO}_{\mathrm{s}}$ & 0.0411 & 0.0493 & 0.0392 & 0.049 & 0.0583 & 0.0571 & 0.0599 & 0.0586 & 0.0493 & 0.0569 & 0.0527 & $* * * * *$ & 0.9979 & 0.9988 & 0.9944 & 0.9957 & 1.0027 & 0.9885 & 0.982 \\
\hline $\mathrm{GOB}_{\mathrm{s}}$ & 0.0241 & 0.0407 & 0.0304 & 0.0344 & 0.0407 & 0.0392 & 0.0397 & 0.0431 & 0.0372 & 0.0447 & 0.0383 & 0.0021 & $* \cdots * *$ & 0.9945 & 0.9909 & 0.9968 & 0.9955 & 0.9965 & 0.9796 \\
\hline $\mathrm{LWR}_{\mathrm{s}}$ & 0.0308 & 0.0407 & 0.0313 & 0.0368 & 0.0463 & 0.0442 & 0.0496 & 0.0441 & 0.0376 & 0.0517 & 0.042 & 0.0012 & 0.0055 & $* * * *$ & 0.9948 & 0.9987 & 0.999 & 0.9957 & 0.984 \\
\hline $\mathrm{NMC}_{\mathrm{s}}$ & 0.0409 & 0.0627 & 0.0525 & 0.0563 & 0.0612 & 0.0584 & 0.0632 & 0.0606 & 0.0602 & 0.0764 & 0.0602 & 0.0056 & 0.0092 & 0.0052 & $* * * * *$ & 0.9909 & 0.9969 & 0.9877 & 0.9652 \\
\hline $\mathrm{RIV}_{\mathrm{s}}$ & 0.0152 & 0.0211 & 0.0163 & 0.0194 & 0.0234 & 0.0232 & 0.0273 & 0.0225 & 0.0213 & 0.0299 & 0.0231 & 0.0043 & 0.0032 & 0.0013 & 0.0091 & $* * * *$ & 0.9971 & 1.0018 & 0.9937 \\
\hline $\mathrm{JAB}_{\mathrm{s}}$ & 0.0330 & 0.0397 & 0.0331 & 0.039 & 0.0483 & 0.0471 & 0.0482 & 0.0477 & 0.0400 & 0.0512 & 0.0442 & -0.0027 & 70.0045 & 0.001 & 0.0031 & 0.0029 & $* \cdots$ & 0.9924 & 0.9879 \\
\hline $\mathrm{TIM}_{\mathrm{s}}$ & 0.0097 & 0.0209 & 0.0173 & 0.015 & 0.0206 & 0.0194 & 0.0209 & 0.0198 & 0.0169 & 0.0292 & 0.0200 & 0.0116 & 0.0035 & 0.0043 & 0.0124 & -0.0018 & 30.0077 & $* * * *$ & 0.9897 \\
\hline $\mathrm{HSB}_{\mathrm{s}}$ & 0.0177 & 0.007 & 0.0077 & 0.0111 & 0.0173 & 0.0186 & 0.0196 & 0.0164 & 0.0118 & 0.0148 & 0.0148 & 0.0181 & 0.0206 & 0.0161 & 0.0354 & 0.0063 & 0.0122 & 0.0104 & $* * * * *$ \\
\hline
\end{tabular}

among populations from the southern group than among populations from northern group (Table 6). Higher genetic diversity in the populations from the southern group was also reported in the mtDNA SSCP study (Apte \& Gardner 2002). Finally, the RAPD analysis has resulted in the UPGMA placement of the HSB population as an outlier, separate from the northern and southern groups, whereas the mtDNA SSCP analysis placed HSB within the southern group. HSB is
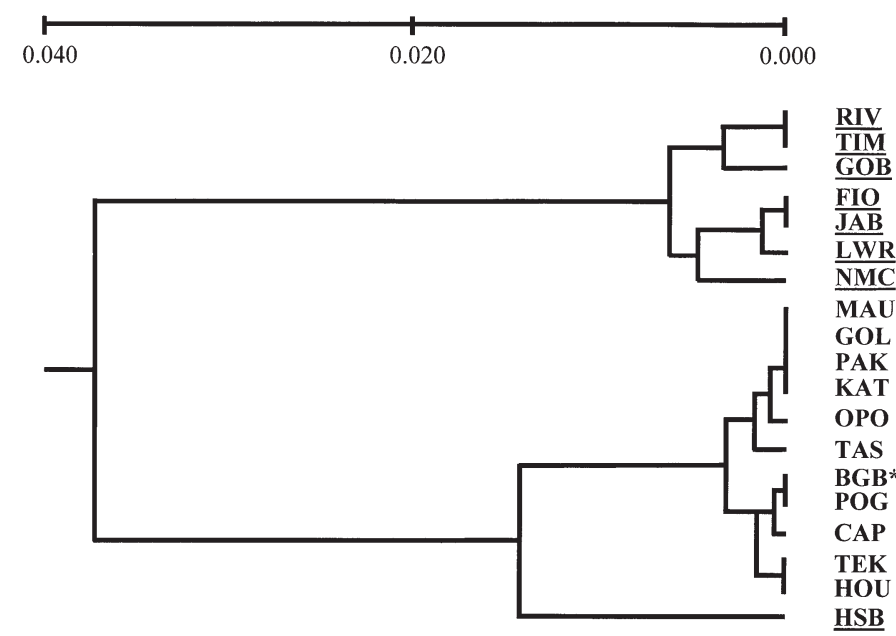

Fig. 5. Perna canaliculus. Relationships between mussel populations inferred from an UPGMA tree reconstructed on the basis of Nei's unbiased genetic distances (1978). Underlined populations belong to the southern group, the other populations belong to the northern group. See Table 1 for abbreviation definitions. BGB*: Big Glory Bay is located geographically in the southern group but falls in the northern cluster of populations because it is an aquaculture population seeded with northern spat from Kaitaia a natural (wild) population, and settlement is derived from wild spat. This population is, however, located only approx. $15 \mathrm{~km}$ from the BGB aquaculture population derived from northern spat. We suggest that the UPGMA placement of HSB as an outlier of the northern group reflects a degree of introgression of northern genes into this southern population, a fact that we were unable to identify from the mtDNA SSCP data because of the absence of haplotypes specific to the northern populations (Apte \& Gardner 2002). In conclusion, the concordance between the mtDNA study (Apte \& Gardner 2002) and this study indicates that both nuclear and mtDNA genomes exhibit pronounced subdivision into northern and southern groups. We therefore reject the hypothesis that population genetic structuring in this species exists only in the mitochondrial genome, and not in the nuclear genome.

The RAPD genetic differentiation reported in this study is in contrast to the biochemical (allozyme) study, which failed to reveal genetic heterogeneity among the same mussel populations (Apte \& Gardner 2001). The ability of RAPD markers to reveal population genetic differentiation when such variation is not detected by allozyme analysis has been reported for marine invertebrate species, including scallops (Patwary et al. 1994, Heipel et al. 1998), and oysters (Hirschfeld et al. 1999). Because RAPDs sample noncoding areas of the genome, they are more likely to represent DNA that is not constrained by selection, whereas allozymes are specific protein products of DNA and typically do not reflect, to the same degree as RAPDs, the underlying DNA variation. On the basis of pronounced population genetic differentiation being revealed by RAPDs, we accept our second hypothesis 
Table 7. Perna canaliculus. $\theta$ (among population component of total population genetic differentiation) estimates among all populations, and among northern and southern populations, and $\chi^{2}$ tests of their significance

\begin{tabular}{|lcrrrrrrrr|}
\hline Population & $\theta$ & SD & $\begin{array}{c}\text { No. of } \\
\text { mussels }\end{array}$ & $\begin{array}{l}\text { No. of } \\
\text { alleles }\end{array}$ & $\begin{array}{c}\text { No. of } \\
\text { populations }\end{array}$ & $\chi^{2}$ & df & $p$ \\
\hline All & 0.092 & 0.055 & 503 & 26 & 19 & 2364.1 & 450 & $<<0.0001$ \\
Northern & 0.012 & 0.008 & 286 & 26 & 11 & 171.6 & 250 & $>0.05$ \\
Southern & 0.028 & 0.016 & 217 & 26 & 8 & 303.8 & 175 & $<0.0001$ \\
\hline
\end{tabular}

same extent, and (3) it is necessary to invoke very high selection coefficients in both the northern and southern regions to generate and maintain the extent of genetic differentiation that we have observed. We therefore discount selection as the major or sole cause of the genetic subdivision we have observed. Secondly, there may be a barrier to larval dispersal between

Table 8. Perna canaliculus. Values of gene flow $\left(\mathrm{Nm}_{\theta}\right)$ among all populations, among northern and southern populations calculated from $\theta$ (Slatkin \& Barton 1989). Lower and upper range values were calculated using the $\mathrm{SD}$ of the $\theta$ values

\begin{tabular}{|lrcc|}
\hline Population & $\mathrm{Nm}_{\theta}$ & Lower range & Upper range \\
\hline All & 2.47 & 1.45 & 6.51 \\
Northern & 20.58 & 12.25 & 62.25 \\
Southern & 8.68 & 5.43 & 20.58 \\
\hline
\end{tabular}

that both the mitochondrial and nuclear genomes have been similarly affected and therefore exhibit similar patterns of population structuring, and that the northsouth genetic discontinuity is only apparent in the faster evolving mtDNA markers, but not in the more evolutionarily constrained allozymes.

Traditionally, high levels of gene flow $\left(\mathrm{Nm}_{\theta}>1\right)$ are thought to be sufficient to prevent population genetic differentiation (Slatkin 1985). However, the pronounced population genetic structuring in Perna canaliculus revealed by RAPDs is maintained despite gene flow estimates of $>1$ migrant per generation. This apparent paradox can be explained by 2 different phenomena, which could be acting independently or simultaneously. Firstly, the genetic discontinuity could be caused by selection against RAPD alleles, or more likely against closely linked functional regions of the genome. That is, when RAPD alleles of one group arrive in the territory of the other group as a result of larval dispersal, they are selected against at some early life-history stage (e.g. larval or spat stage). The selective agent responsible for the genetic discontinuity would need to act over large spatial scales, and therefore the most likely cause would seem to be one or more environmental conditions (e.g. temperature). This scenario seems unlikely for the following reasons: (1) RAPD genetic subdivision occurs over a narrow spatial scale, and there are no indications that environmental conditions change in a similar fashion, (2) despite the fact that the mitochondrial and nuclear genomes are physically unlinked, we have observed fundamentally the same pattern of discontinuity in both genomes, meaning that we have to postulate a process or processes that affect both genomes to the northern and southern populations. Estimates of gene flow (Table 8) within the northern $\left(\mathrm{Nm}_{\theta}=20\right)$ and southern $\left(\mathrm{Nm}_{\theta}=9\right)$ groups are high, whereas estimates of gene flow between the groups are lower $\left(\mathrm{Nm}_{\theta}=2.5\right)$, but still high in absolute terms. We note that the mtDNA (Apte \& Gardner 2002) and RAPD data both revealed a pronounced genetic discontinuity just below the north end of the South Island, at $\sim 42^{\circ} \mathrm{S}$. While we did not observe any fixed RAPD allele differences between the northern and southern groups, we did observe 5 significant allelic frequency differences between these groups, 3 of which were very pronounced. This genetic differentiation is reinforced by the presence of a unique southern mtDNA SSCP haplotype at a frequency of $20 \%$, despite high estimates of gene flow estimated from the mtDNA data (Apte \& Gardner 2002). It seems highly unlikely that nuclear and mtDNA differences of these magnitudes can be maintained in the face of such high levels of gene flow, in particular when selection as an explanation has been discounted. We therefore suggest that the apparently high levels of gene flow between the 2 groups result from the genotypic and allelic similarities that existed historically between these regions, but do not reflect present day values of gene flow. We predict that gene flow between the northern and southern populations is in fact very low, if not entirely absent, a situation which results from a combination of unique hydrographical features at $\sim 42^{\circ} \mathrm{S}$ (Apte \& Gardner 2002).

Nearshore oceanographic processes play a critical role in determining recruitment patterns of coastal species (Botsford 2001, and references therein). The dispersal of the planktonic larvae of Perna canaliculus is dependent on the major coastal surface water flows around New Zealand (described by Stanton 1976, Bowman et al. 1983, Barnes 1985, Heath 1985, Harris 1990, Vincent \& Howard-Williams 1991, Stanton \& Moore 1992, Chiswell 2000, and references therein) (Fig. 6). Although we are presently unable to identify the exact location of the genetic discontinuity, it does not coincide with the geographic location of 2 major features in this part of New Zealand. The genetic break occurs south of Cook Strait, and north of the (indistinct) boundary between the Cookian (cold temperate mixed waters) and the Forsterian (transitional between sub- 
antarctic cold temperate waters and cold temperate mixed waters) biogeographic provinces (Ekman 1967, Briggs 1974, Knox 1975). The hydrography around the northern end of the South Island is therefore of special interest, because the genetic break between northern and southern populations is present in this area. The D'Urville Current mixes with the Southland Current and the East Cape Current (Barnes 1985), and part of this mixed water flows north as the Wairarapa Coastal Current (Chiswell 2000). Tidal currents within Cook Strait can be very high $\left(250 \mathrm{~cm} \mathrm{~s}^{-1}\right)$ compared to other tidal currents around New Zealand ( 10 to $20 \mathrm{~cm} \mathrm{~s}^{-1}$ ) (Stanton et al. 2001). On the NE and NW coasts of the South Island, extensive and prolonged upwelling can occur (Bowman et al. 1983, Harris 1990). During these upwelling events, larvae in surface coastal waters will be carried offshore and lost to coastal systems. On the east coast in this region, the permanent Wairarapa Eddy is known to trap the larvae of many species (Bowman et al. 1983, Vincent \& Howard-Williams 1991, Chiswell \& Booth 1999). These upwelling events along both coasts, in conjunction with the known eddies, gyres, and associated turbulence of the Greater Cook Strait region, may be acting as a barrier to the movement of larvae of $P$. canaliculus between southern and northern regions (Apte \& Gardner 2002). If this is the case, then other species with similar reproductive strategies, such as the ribbed mussel Aulacomya maorina and the blue mussel Mytilus galloprovincialis, are likely to exhibit similar population genetic structuring (Apte \& Gardner 2002). Future research will test this hypothesis.

In conclusion, this study observed strong population genetic structuring among 19 populations of the endemic New Zealand greenshell mussel Perna canaliculus using the RAPD technique. These results contrast with those from our allozyme study of the same mussels (Apte \& Gardner 2001), but agree with data from our mtDNA study of the same mussels (Apte \& Gardner 2002). Because the location of the genetic discontinuity is coincident with a combination of hydrographical features at $\sim 42^{\circ} \mathrm{S}$, we believe that these hydrographical features act as barrier to gene flow between northern and southern populations. We suggest that the high estimates of gene flow calculated from our allozyme, mtDNA, and RAPD data reflect historical similarities between northern and southern populations, which are now in the process of differentiating as a consequence of the absence of gene flow between them.

\section{LITERATURE CITED}

Adamkewicz SL, Harasewych MG (1994) Use of random amplified polymorphic DNA (RAPD) markers to assess relationships among beach clams of the genus Donax. The Nautilus (Suppl) 2:51-60
Adamkewicz SL, Harasewych MG (1996) Systematics and biogeography of the genus Donax (Bivalvia: Donacidae) in eastern North America. Am Malacol Bull 13:97-103

André C, Lindegarth M, Jonsson PR, Sundberg P (1999) Species identification of bivalve larvae using random amplified polymorphic DNA (RAPD): differentiation between Cerastoderma edule and C. lamarcki. J Mar Biol Assoc UK 79:563-565

Apte S, Gardner JPA (2001) Absence of population genetic differentiation in the New Zealand greenshell mussel Perna canaliculus (Gmelin 1791) as assessed by allozyme variation. J Exp Mar Biol Ecol 258:173-194

Apte S, Gardner JPA (2002) Population genetic subdivision in the New Zealand greenshell mussel (Perna canaliculus) inferred from single-strand conformation polymorphism analysis of mitochondrial DNA. Mol Ecol 11: 1617-1628

Backeljau T, De Bruyn L, De Wolfe H, Jordaens K, Van Dongen S, Winnepenninckx B (1996) Multiple UPGMA and Neighbor-joining trees and the performance of some computer packages. Mol Biol Evol 13:309-313

Barnes EJ (1985) Eastern Cook Strait region circulation inferred from satellite-derived sea-surface, temperature data. NZ J Mar Freshw Res 19:405-411

Botsford LW (2001) Physical influences on recruitment to California Current invertebrate populations on multiple scales. ICES J Mar Sci 58:1081-1091

Bowman MJ, Kibblewhite AC, Murtagh RA, Chiswell SM, Sanderson BG (1983) Circulation and mixing in greater Cook Strait, New Zealand. Oceanol Acta 6:383-391

Briggs JC (1974) Marine zoogeography. McGraw-Hill Book Company, New York

Buchanan SJ (1994) The settlement behaviour and recruitment of Perna canaliculus. MSc thesis, University of Auckland

Caccone A, Allegrucci G, Fortunato C, Sbordoni V (1997) Genetic differentiation within the European sea bass $(D$. labrax) as revealed by RAPD-PCR assays. J Hered 88: 316-324

Chiswell SM (2000) The Wairarapa coastal current. NZ J Mar Freshw Res 34:303-315

Chiswell SM, Booth JD (1999) Rock lobster Jasus edwardsii larval retention by the Wairarapa Eddy off New Zealand. Mar Ecol Prog Ser 183:227-240

Crossland S, Coates D, Grahame J, Mill PJ (1996) The Littorina saxatilis species complex-interpretation using random amplified polymorphic DNAs. In: Taylor J (ed) Origin and evolutionary radiation of the Mollusca. Oxford University press, Oxford, p 205-209

Ekman S (1967) Zoogeography of the Sea. Sidgwick \& Jackson, London

Gardner JPA, Pande A, Eyles, RF, Wear RG (1996) Biochemical genetic variation among populations of the greenshell mussel, Perna canaliculus, from New Zealand: preliminary findings. Biochem Syst Ecol 24:763-774

Goldson AJ, Hughes RN, Gliddon CJ (2001) Population genetic consequences of larval dispersal mode and hydrography: a case study with bryozoans. Mar Biol 138:1037-1043

Harris TFW (1990) Greater Cook Strait, form and flow. DSIR Marine and Freshwater Division, Wellington

Hayden BJ (1994) What do we know about greenshell mussel spat? Part I. Seafood NZ 2:45-47

Heath RA (1985) A review of the physical oceanography of the seas around New Zealand-1982. NZ J Mar Freshw Res 19:79-124

Heipel DA, Bishop JDD, Brand AR, Thorpe JP (1998) Population genetic differentiation of the great scallop Pecten maximus 
in western Britain investigated by randomly amplified polymorphic DNA. Mar Ecol Prog Ser 162:161-171

Hellberg ME, Burton RS, Hedgecock D, Neigel JE, Palumbi SR (2002). The use of genetic data to assess connectivity among marine populations. Bull Mar Sci 70(1)Suppl $273-290$

Hirschfeld BM, Dhar AK, Rask K, Alcivar-Warren A (1999) Genetic diversity in the eastern oyster (Crassostrea virginica) from Massachusetts using the RAPD technique. J Shellfish Res 18:121-125

Holm S (1979) A simple sequentially rejective multiple test procedure. Scand J Stat 6:65-70

Jones S (2000) Annual report of the Treaty of Waitangi Fisheries Commission (Te Ohu Kai Moana), Wellington

Knox GA (1975) The marine benthic ecology and biogeography. In: Kuschel G (ed) Biogeography and ecology in New Zealand. Monographiae Biologicae, Vol 27. Dr W Junk b.v. Publishers, The Hague, p 353-403

Lynch M, Milligan BG (1994) Analysis of population structure genetic structure with RAPD markers. Mol Ecol 3:91-99

Ma XL, Cowles DL, Carter RL (2000) Effect of pollution on genetic diversity in the bay mussel Mytilus galloprovincialis and the acorn barnacle Balanus glandula. Mar Environ Res 50:559-563

Nei M (1978) Estimation of average heterozygosity and genetic distance from a small number of individuals. Genetics 89:583-590

Patwary MU, Kenchington EL, Bird CJ, Zouros E (1994) The use of random amplified polymorphic DNA markers in genetic studies of the sea scallop Placopecten magellanicus (Gmelin, 1791). J Shellfish Res 13:547-553

Rawson PD, Hilbish TJ (1995) Evolutionary relationships among the male and female mitochondrial DNA lineages in the Mytilus edulis species complex. Mol Biol Evol 12: 893-901

Raymond ML, Rousset F (1995) An exact test for population differentiation. Evolution 49:1280-1283

Rice WR (1989) Analyzing tables of statistical tests. Evolution 43:223-225

Slatkin M (1985) Gene flow in natural populations. Annu Rev Ecol Syst 16:393-430

Slatkin M, Barton NH (1989) A comparison of three indirect methods for estimating average level of gene flow. Evolution 43:1349-1368

Editorial responsibility: Otto Kinne (Editor), Oldendorf/Luhe, Germany
Smith PJ (1988) Biochemical-genetic variation in the greenlipped mussel Perna canaliculus around New Zealand and possible implications for mussel farming. NZ J Mar Freshw Res 22:85-90

Smith PJ, Roberts CD, McVeagh SM, Benson PG (1996) Genetic evidence for 2 species of tarakihi (Teleostei: Cheilodactylidae: Nemadactylus) in New Zealand waters. NZ J Mar Freshw Res 30:209-220

Smith PJ, Benson PG, McVeagh SM (1997) A comparison of three genetic methods used for stock discrimination of orange roughy, Hoplostethus atlanticus: allozymes, mitochondrial DNA, and randomly amplified polymorphic DNA. Fish Bull 95:800-811

Sokal R, Rohlf FL (1995) Biometry. WH Freeman, New York

Sommerfeldt AD, Bishop JDD (1999) Random amplified polymorphic DNA (RAPD) analysis reveals extensive natural chimerism in a marine protochordate. Mol Ecol 8:885-890

Stanton BR (1976) Circulation and hydrology off the West Coast of the South Island, New Zealand. NZ J Mar Freshw Res 10:445-467

Stanton BR, Moore MI (1992) Hydrographic observations during the Tasman Boundary Experiment off the West Coast of the South Island, New Zealand. NZ J Mar Freshw Res 26:339-358

Stanton BR, Goring DG, Bell RG (2001) Observed and modeled tidal currents in the New Zealand region. NZ J Mar Freshw Res 35:397-415

Swearer SE, Shima JS, Hellberg ME, Thorrold and 7 others (2002) Evidence of self-recruitment in demersal marine populations. Bull Mar Sci 70(1)Suppl:251-271

Vincent WF, Howard-Williams (1991) Distribution and biological properties of oceanic water masses around South Island, New Zealand. NZ J Mar Freshw Res 25:21-42

Waples RS (1987) A multi species approach to the analysis of gene flow in marine shore fishes. Evolution 41:385-400

Weir BS, Cockerham CC (1984) Estimating F-statistics for the analysis of population structure. Evolution 38:1358-1370

Welsh J, McClelland M (1990) Fingerprinting genomes using PCR with arbitrary primers. Nucleic Acids Res 18: 7213-7218

Williams JGK, Kubelik AR, Livak KJ, Rafalski JA, Tingey SV (1990) DNA polymorphisms amplified by arbitrary primers are useful as genetic markers. Nucleic Acids Res 18: $6531-6535$

Submitted: February 4, 2002; Accepted: October 22, 2002 Proofs received from author(s): February 17, 2003 